\title{
Odun hammaddesi üretiminde çalışanların geçirdikleri iş kazası ve meslek hastalıkları yönünden değerlendirilmesi
}

Evaluation of the occupational accidents and diseases of the employees in the production of wood raw materials

Emre GÖKSU'

Hadiye BAŞAR

Mehmet EROL ${ }^{2}$

${ }^{1}$ Ege Ormanc1lık Araştırma Enstitüsü
Müdürlüğü, İzmir
${ }^{2}$ İzmir Orman Bölge Müdürlüğü, İzmir

Sorumlu yazar (Corresponding author) Emre GÖKSU

goksuemre@hotmail.com

Geliş tarihi (Received)

12.11.2019

Kabul tarihi (Accepted)

06.04 .2020

Sorumlu editör (Corresponding editor)

Neşat ERKAN

nesaterkan@yahoo.com

Atıf (To cite this article): GÖKSU, E, BASAR, H , EROL, M . (2020). Odun hammaddesi üretiminde çalışanların geçirdikleri iş kazası ve meslek hastalıkları yönünden değerlendirilmesi. Ormancılık Araştırma Dergisi , 7 (2), 120-130 DOI: https://doi.org/10.17568/ogmoad.645878

\section{Öz}

Bu çalışmada, sadece odun hammaddesi üretiminde çalışan işçilerin değil, aynı zamanda teknik elemanların da yaşadıkları iş kazaları ve meslek hastalıkları üzerine değerlendirmeler yapılarak konu ile ilgili önemli bir sorun olan veri eksikliğinin giderilmesine çalışılmış, daha sonra kazaların gerçekleştiği andaki faaliyetler incelenerek alınacak tedbirlerin belirlenmesi için öneriler getirilmiştir. Bu kapsamda Menderes Orman İşletme Müdürlügü’nde odun hammaddesi üretim faaliyetlerinde görevli olan tüm teknik elemanlar ve üretim işçileri ile yüz yüze görüşme yöntemi kullanılarak anket uygulanmıştır. Elde edilen veriler değerlendirildiğinde; üretim işinde çalışanların \%88,3'ünün son üç y1l içerisinde en az bir kez kaza geçirdiği, öğrenim düzeyi ve yaşın, çalışılan zemin durumunun, hava şartlarının ve arazi eğiminin kaza geçirme sıklığını etkilediği görülmüştür. Ayrıca çalışanların \%70,9'unun meslek hayatları süresince üretim işlerine bağlı olarak tedavi gerektiren bir hastalık tanısı aldıkları, özellikle üretim ve ev işlerini birlikte yerine getiren kadınların erkeklere göre daha fazla sağlık sorunu yaşadığ 1 tespit edilmiştir.

Anahtar Kelimeler: Odun hammaddesi üretimi, çalışanlar, iş kazalar1, meslek hastalıkları

\section{Abstract}

In this study, not only the workers working in the production of wood raw materials but also the technical staffs were evaluated on the occupational accidents, diseases and the data deficiency, which is an important problem, was tried to be solved. Then, the activities at the time of the accidents were examined and recommendations were made to determine the measures to be taken. In this context, a questionnaire was applied to all technical staff and production workers involved in wood raw material production activities at Menderes Forest Enterprise Directorate using face-to-face interview method. When the data obtained are evaluated; it has been observed that $88.3 \%$ of the workers in the production business had an accident at least once in the last three years, and the level of education, age, the ground conditions worked, the weather conditions and the slope of the land affected the frequency of the accident. In addition, it was determined that $70.9 \%$ of the employees were diagnosed with a disease that requires treatment during their professional life, especially women who perform the production and household affairs together have more health problems than men.

Keywords: Wood raw material production, employees, occupational accidents, occupational diseases 


\section{Giriş}

Odun hammaddesi üretim faaliyetleri çok farklı coğrafi ve iklimsel koşullar altında, tamamen dış ortamda, yetişme ortamına göre değişen farklı türlerdeki ağaçlarda, yine yapılan iş çeşidine göre değişen çeşitli makineler kullanılarak gerçekleştirilmektedir. Genellikle emek-yoğun çalışılan bu sektörde geniş kapsamlı çalışan profilleri risk düzeyini arttırmakta ve sektörde meydana gelen iş kazalarını ve meslek hastalıklarını önlemeye yönelik tutumları önemli ölçüde etkilemektedir. "Tehlikeli İşler” sınıfında (T.C. Resmi Gazete, 2017) yer alan odun hammaddesi üretim işlerinde çalışanlar her yıl birçok iş kazalarına ve meslek hastalıklarına maruz kalmaktadırlar (SGK, 2018). Orman Genel Müdürlüğü (OGM) sürdürülebilir orman yönetimini sağlamak için 2010 yılında başlatmış olduğu sertifikalandırma çalışmalarında Forest Stewardship Council (FSC) programını tercih ederek bu kapsamda önemli bir adım atmıştır.

Türkiye'de iş kazaları ve meslek hastalıkları ile ilgili birçok farklı alanda araştırmalar yapılmasına rağmen, ülke ekonomisine önemli katkılar sağlayan odun hammaddesi üretim faaliyetlerinde çal1şanların geçirdikleri iş kazaları ve meslek hastalıkları ile ilgili çalışmalar önemli görülmekle birlikte sayıları sınırlıdır. Konu ile ilgili; Yusufeli Orman İşletme Müdürlüğü'nde üretim işlerinde çalışan 35 işçi ile görüşerek işçilerin sahip olduğu sağlık sorunlarını belirlemeye çalışan Acar ve Şentürk (1997); bölgedeki üretim işçilerinin \%40,3'ünün tansiyon sorunu yaşadı $\breve{g}_{1}, \% 40,5$ oranla romatizma, \%33,4 oranla da sırt ağrılarının olduğunu belirlemişlerdir. Üretim işçilerinin \%51,2'si el-ayak üşümesine sahipken, \%39,5'i uykusuzluk sorunu yaşamakta ve \%38,6's1 da sinirli bir ruh halinde olduğunu ifade etmişlerdir. Menemencioğlu (2006), beş farklı bölgede toplam 250 orman işçisi ile yaptığ 1 görüşmelerde \%47'sinin en az bir defa iş kazaS1 geçirdiğini vurgulayarak, iş kazası geçirenlerin kaza şeklinde; \%51'inde yaralanma (kesilme-zedelenme), \%36'sında ise kırılma, burkulma ve çıkma şeklinde ortopedik kazalar olduğu belirlemiştir. Yaralanma olaylarının en çok \%17 oranla el-kol ve \%16 da oranla ayak-bacaklarda olduğu görülmüştür.

Enez ve ark. (2009), Trabzon Orman Bölge Müdürlüğü kapsamında üretim işlerinde çalışan orman işçilerinin beden kitle indeksi ile bel-kalça oranlarını hesaplamışlar ve iş kazası geçirme açısından risk faktörü olarak değerlendirme olanağını araştırılmışlardır. 378 orman işçisi ile yüz yüze görüşme yoluyla yapılan çalışmada; son bir yılda çalışanlarda kaza geçirme durumuna göre beden kitle indeksi normal olanların \%29,8'i kaza geçirmişken, kiloluların \% 38,1'i ve obezlerin \% 39,1'i kaza geçirmişlerdir. Sonuç olarak beden kitle indeksi ve bel-kalça oranları arttıkça kaza geçirme sıklığının artığını vurgulamışlardır. Çolak ve ark. (2011), Trabzon Orman Bölge Müdürlüğü sınırları içerisinde 346 orman üretim işçisi ile gerçekleştirdikleri çalışmalarında; \%56,1'inin meslek hayatı süresince en az bir kere kaza geçirdiğini ortaya koymuşlardır. Meydana gelen kaza çeşitlerine bakıldığında ise en fazla oranın kayıp-düşme $(\% 38,2)$ ve tomruk, odun veya bir başka parçanın çarpması $(\% 36,4)$ olduğu belirlenmiştir. Kazanın gerçekleştiği andaki iş faaliyetleri ise $\% 38,1$ ile elle sürütme, $\% 19,1$ ile kabuk soyma ve \%18,6 ile ağaç kesme olarak tespit edilmiştir. \%44,2'si tedavi gerektiren bir hastalık tanısı alan işçilerin \%11,3 yüksek tansiyon, $\% 6,6$ 'sı bronşit hastasıdır.

Gümüş ve Türk (2012), orman üretim işçilerinin çalışma koşullarını incelemiş ve anket çalışması yaparak başlıca sağlık sorunlarının tespit etmeye çalışmışlardır. Adana, Artvin ve İzmir illerinde toplam 140 işçi ile yapılan çalışmada işçilerin $\% 75,7$ 'sinde sağlık sorunları olduğu belirlenerek \%77,9'unun bel ağrılarından şikayetçi olduğu, \%43,6'sının omuz ve kürek kemiği ağrılarının bulunduğu görülmüştür. Üretim faaliyetleri sırasında işçilerin \%35'i bir iş kazası yaşadığını belirtmiştir. Bu kazaların \%58,1'i ayak ve ayak parmaklarına, $\% 22,6$ 's 1 el ve el parmaklarına zarar vermiştir. Kaza sonrasında vücutta bıraktığı yaralanmaların \%69'unu ezilme-burkulma, \%13,8'ini bel-boyun fitığ 1 \% \%,9'unu kemiklerde kırılma oluşturmaktadır. Çalışanların \%49,3'ü ise psikolojik rahatsızlık (yorgunluk, hissi, halsizlik vb.) hissetmekte olduğunu bildirmişlerdir. Ünver ve ark. (2013), büyük oranda el aletleri ile gerçekleştirilen hasat ve bölmeden çıkarma çalışmalarındaki ergonomik riskleri değerlendirmişlerdir. Hasat faaliyeti sırasında yapılan kaldırma, tutma ve taşıma işlerine ait risk puanı hesaplamalarına göre ormancılıkta motorlu testere taşıma ve kullanma işi ile bölmeden çıkarma işlerinde çalışan işçilerin aşırı yüklenmeden kaynaklı kas iskelet sistemi rahatsızlıkları yaşama olasılıklarının yüksek olduğunu ortaya koymuşlardır.

Araştırma konusu ile ilgili önceki çalışmalar değerlendirildiğinde hemen hemen tamamında odun hammaddesi üretiminde çalışan işçiler ile ilgili bilgiler toplanarak daha çok işçi sağlığı üzerinde durulduğu görülmektedir. Oysaki üretim işlerinin başlamasından bitimine kadar olan süreçte OGM'ye bağlı teknik elemanlar (orman mühendisleri ve orman muhafaza memurları) da bizzat görev almakta ve buna bağlı olarak iş kazaları ve meslek hastalıklarına yakalanma olasılıkları her zaman mevcut olmaktadır. Dolayısıyla bu çalışmada diğer 
çalışmalardan farklı olarak sadece odun hammaddesi üretiminde çalışan işçilerin değil, aynı zamanda teknik elemanların da yaşadıkları iş kazaları ve meslek hastalıkları üzerine değerlendirmeler yapılarak konu ile ilgili önemli bir sorun olan veri eksikliğinin giderilmesine katkı sağlanması amaçlanmıştır.

\section{Materyal ve Yöntem}

\subsection{Materyal}

$\mathrm{Bu}$ çalışma, İzmir Orman Bölge Müdürlüğü (İOBM) sınırları içerisinde yer alan İzmir ili Menderes Orman İşletme Müdürlüğü $\left(\mathrm{MOİM}^{1}\right)$ ve bağlı şefliklerde uygulanmıştır. Araştırmada birincil verileri toplama materyali olarak; hazırlanan anket formlarından, odun hammaddesi üretim faaliyetlerine ilişkin oluşturulan tehlikelere göre risk seviyesi tespit tablolarından, literatürde yer alan çalişmalardan ve İOBM ile MOİM kayıtlarından elde edilen veriler kullanılmıştır.

Üretim faaliyetlerinde çalışanların demografik özellikleri, faaliyetlerin gerçekleştiği arazi yapısı ve hava şartları ile iş kazaları ve meslek hastalıklarının meydana gelme durumu arasında istatistiksel olarak anlamlı bir fark olup olmadığının belirlenmesi için gerekli olan veriler oluşturulan anket formu yardımıyla elde edilmiştir. Anket formları; araştırmanın amaçları göz önünde tutularak incelenen ulusal ve uluslararası literatür ve ormancılık sektörü dışındaki tarım, inşaat, madencilik vb. sektörlerin yaptığı çeşitli çalışmalardan elde edilen bilgiler yardımıyla hazırlanmıştır.

\subsection{Yöntem}

MOİM sınırları içerisinde odun hammaddesi üretimi faaliyetlerinde görev alan tüm çalışanlar "üretim işçileri" ve "teknik elemanlar" (mühendis, orman muhafaza memuru) olmak üzere iki ayrı gruba ayrılmıştır. Çalışmada herhangi bir örnekleme yapılmamış, ana kütle hakkındaki en geniş bilgiyi elde etmek amacı ile tam sayım yöntemi kullanılmıştır. Araştırmanın gerçekleştiği dönemde çeşitli nedenlerle kurum dışında bulunan ve izinli sayılan çalışanlar ile anket formları doldurulamamıştır. Herhangi bir kavram kargaşasına sebebiyet vermemek için ilk önce 6331 sayılı İş Sağlığı ve Güvenliği Kanunu (T.C. Resmi Gazete, 2012)'nda yer alan "iş kazası" ve "meslek hastalığı" kavramları ayrıntılı bir şekilde çalışanlara açıklanmış, bu aşamadan sonra anket formalarının doldurulmas1na başlanmıştır. Sonuçta, 66 “üretim işçisi” ve 37

$1 \mathrm{Bu}$ işletmenin adı 11.11.2019 tarih ve 30945 sayılı Resmi Gazete'de Gaziemir Orman İşletme Müdürlüğü olarak değiştirilmiştir. “teknik eleman” olmak üzere toplam 103 kişi ile yüz yüze görüşülmüştür.

Çalışanların demografik özelliklerinin yanı sıra, son üç yılda üretim faaliyetleri sırasında iş kazası geçirme durumu, kaza anında hangi faaliyetin yapıldığ 1 , kaza sayısı, kaza anındaki zemin durumu, hava şartları, arazi eğimi ve sağlık açısından var olan rahatsızlıklar ile ilgili istatistiki değerlendirmeler yapılmıştır. Anketlerden elde edilen verilerin değerlendirilmesinde tanımlayıcı istatistikler (frekans, yüzde yöntemi vb.), tablolar ve şekiller kullanılmıştır. Araştırmanın varsayımlarından olan; odun hammaddesi üretiminde çalışanların demografik özellikleri ve çalışma alanının zemin durumu, arazi eğimi ve hava şartları ile iş kazaları ve meslek hastalıklarının meydana gelmesi arasındaki ilişki parametrik olmayan testlerden Ki-kare testi, Mann Whitney- $U$ testi ve Kruskal Wallis- $H$ testi kullanılarak incelenmiştir.

\section{Bulgular}

\subsection{Odun hammaddesi üretiminde çalışanların demografik özellikleri}

Uygulanan anketler sonucu odun hammaddesi üretiminde çalışanların cinsiyet, yaş, eğitim durumu ve hizmet süresi gibi özelliklerinin sayısal ve oransal olarak dağılımları Tablo 1'de gösterilmiştir.

Tablo 1'e göre; odun hammaddesi üretiminde çal1şanların ağırlıklı olarak $(\% 89,3)$ erkek olduğu tespit edilmiştir. Kadın çalışanların oranı ise $\% 10,7$ 'dir. Çalışanların görevlerine göre cinsiyet dağılımına bakıldığında ise; üretim işçilerinin $\% 15,2$ 'si, teknik elemanların da \%2,7'si kadınlardan oluşmaktadır.

Ankete katılan tüm çalışanların en yoğun olduğu yaş grubu \%29,13 ile 35-44 iken bunu sirasiyla $\% 27,18$ ile $45-54$ yaş grubu, \% 21,36 ile 55-65 yaş grubu, $\% 5,83$ 'ile de 18-24 yaş gurubu izlemektedir.

Üretim işlerinde çalışan üretim işçilerinin $\% 4,5$ 'i herhangi bir okuldan mezun değildir. \%77,3 gibi büyük bir çoğunluğu ise ilköğretim mezunu, $\% 18,2$ 'si lise mezunudur. Teknik elemanlardan “orman muhafaza memurları”nın \%18,9'u ilköğretim, \%35,1'i lise ve \%5,4’ü ön lisans mezunudur.

Odun hammaddesi üretiminde çalışanların $\% 12,6$ 's1 5 y1l ve daha az, \%15,5'i 6-10 yıl, \%16,5'i $11-15$ y1l, \%12,6's1 16-20 ve \%42,7'si 21 y1l ve daha fazla hizmet süresine sahip olup hizmet süresinin 21 yıl ve üstünde yoğunlaştığ 1 görülmektedir (Tablo 1).

Yine Tablo 1 incelendiğinde; üretim işçilerinin hizmet süresi 5 yıl ve daha az yıl olanların ora- 
Tablol. Çalışanların demografik özellikleri

Table1. Demographic characteristics of the employees

\begin{tabular}{|c|c|c|c|c|c|c|c|}
\hline & & \multicolumn{2}{|c|}{ Üretim İşçileri } & \multicolumn{2}{|c|}{ Teknik Elemanlar } & \multicolumn{2}{|c|}{ Toplam } \\
\hline & & Say1 & $\%$ & Say1 & $\%$ & Say1 & $\%$ \\
\hline \multirow{3}{*}{ Cinsiyet } & Kadın & 10 & 15,2 & 1 & 2,7 & 11 & 10,7 \\
\hline & Erkek & 56 & 84,8 & 36 & 97,3 & 92 & 89,3 \\
\hline & Toplam & 66 & 100,0 & 37 & 100,0 & 103 & 100,0 \\
\hline \multirow{6}{*}{ Yaş grupları } & $18-24$ & 6 & 9,09 & 0 & 0,00 & 6 & 5,8 \\
\hline & $25-34$ & 12 & 18,18 & 5 & 13,6 & 17 & 16,5 \\
\hline & $35-44$ & 20 & 30,30 & 10 & 27,0 & 30 & 29,1 \\
\hline & $45-54$ & 17 & 25,76 & 11 & 29,7 & 28 & 27,2 \\
\hline & $55-65$ & 11 & 16,67 & 11 & 29,7 & 22 & 21,4 \\
\hline & Toplam & 66 & 100,0 & 37 & 100,0 & 103 & 100,0 \\
\hline \multirow{7}{*}{ Eğitim durumu } & <İlköğretim & 3 & 4,5 & 0 & 0,0 & 3 & 2,9 \\
\hline & İlköğretim & 51 & 77,3 & 7 & 18,9 & 58 & 56,3 \\
\hline & Lise & 12 & 18,2 & 13 & 35,1 & 25 & 24,3 \\
\hline & Ön Lisans & 0 & 0,0 & 2 & 5,4 & 2 & 1,9 \\
\hline & Lisans & 0 & 0,0 & 14 & 37,8 & 14 & 13,6 \\
\hline & Y. Lisans & 0 & 0,0 & 1 & 2,7 & 1 & 1,0 \\
\hline & Toplam & 66 & 100,0 & 37 & 100,0 & 103 & 100,0 \\
\hline \multirow{6}{*}{$\begin{array}{l}\text { Hizmet süresi } \\
\text { (y1l) }\end{array}$} & $\leq 5$ & 10 & 15,2 & 3 & 8,1 & 13 & 12,6 \\
\hline & $6-10$ & 12 & 18,2 & 4 & 10,8 & 16 & 15,5 \\
\hline & $11-15$ & 9 & 13,6 & 8 & 21,6 & 17 & 16,5 \\
\hline & $16-20$ & 12 & 18,2 & 1 & 2,7 & 13 & 12,6 \\
\hline & $21 \geq$ & 23 & 34,8 & 21 & 56,8 & 44 & 42,7 \\
\hline & Toplam & 66 & 100,0 & 37 & 100,0 & 103 & 100,0 \\
\hline
\end{tabular}

n1 \%15,2 iken teknik elemanların oranı \%8,1'dir. Hizmet süresi 21 yıl ve daha fazla olanların oranı üretim işçilerinde $\% 34,8$ iken teknik elemanlarda $\% 56,8$ 'dir. Buna göre; teknik elemanlar hizmet süresi bakımından üretim işçilerine göre daha fazla tecrübeye sahiptirler. Ki-kare analizi sonucunda hizmet süresinin yapılan görevlere göre farklı olduğu saptanmıştır $\left(x^{2}=9,842 ; s d=4 ; p=0,043\right)$.

\subsection{Odun hammaddesi üretiminde çalışanların iş kazası geçirme durumları}

Odun hammaddesi üretim işinde çalışanların \%88,3'ü son üç yılda en az bir kez iş kazası geçirdiğini belirtmiştir. Bu oran üretim işçilerinde \%89,4 iken teknik elemanlarda \%86,5 olarak gerçekleşmiştir (Şekil 1).

İşçiler üretim faaliyetleri sırasında \%23,4 ile en çok "ağaç kesme" işinde kaza geçirmişlerdir. Bunu ikinci sırada \%13,9 ile "istifleme", üçüncü sırada \%12,0 ile "yükleme-boşaltma", dördüncü sırada $\% 9,5$ ile "boylama", beşinci sırada \%8,9 ile "traktör ile sürütme", altıncı sırada \%8,2 ile "taşıma", yedinci sırada \%7,6 ile "kabuk soyma", sekizinci sirada \%5,7 ile "dal temizleme", dokuzuncu sirada \%4,4 ile "ulaşım" faaliyetleri izlemektedir. En az kaza ise \%3,2 ile "elle sürütme" ve "diğer" faaliyetlerde gerçekleşmektedir (Şekil 2). "Elle sürüt- me" faaliyetinin kaza oranının düşük olmasının en önemli nedeni yörede bölmeden çıkarma işleminin elle yapılması yerine traktörün daha yaygın olarak kullanılması gösterilebilir.

Şekil 1. Üretim işinde çalışanların son üç yılda iş kazas1 geçirme oranlar1

Figure 1. Occupational accident rates of the workers in the last three years

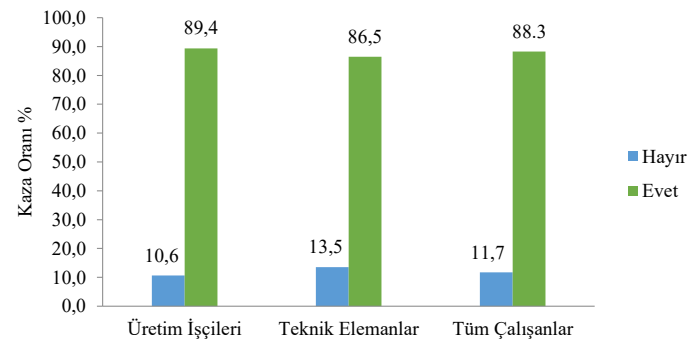

Üretim faaliyetleri sırasında teknik elemanların yaşadığı en çok kaza \%43,3 ile “damgalama”, \%32,8 ile "denetleme-kontrol" faaliyetlerinde gerçekleşirken, en az kaza ise \%6,0 ile "üretim alanına ulaşım" faaliyetinde meydana gelmiştir (Şekil 3).

\subsubsection{Demografik özelliklere göre iş kazaları}

Çalışanların kaza geçirme durumunun demografik özelliklere göre değişip değişmediğini belirlemek 
Şekil 2. İşçilerin üretim işinde kazanın gerçekleştiği andaki faaliyet ve oranları

Figure 2. The activities and rates of workers at the time of the occupational accident in the production work

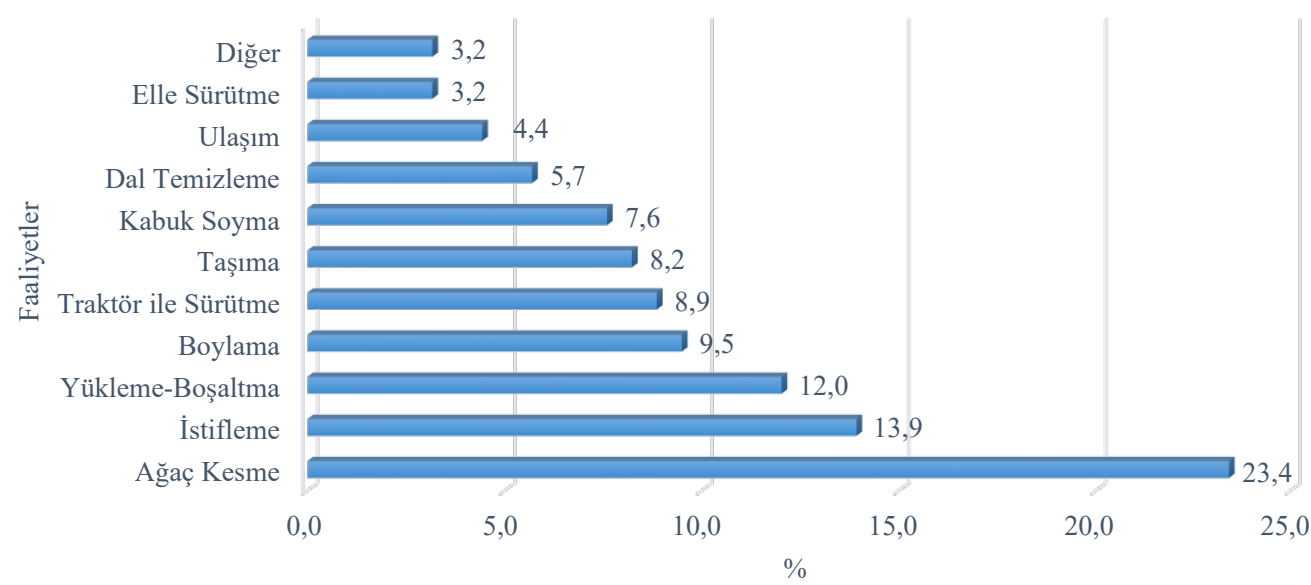

amacıyla çalışanların son üç yıl içinde geçirdikleri

Şekil 3. Teknik elemanların üretim işinde kazanın gerçekleştiği andaki faaliyet ve oranları

Figure 3. Activities and rates of technical personnel in the production business at the time of the accident

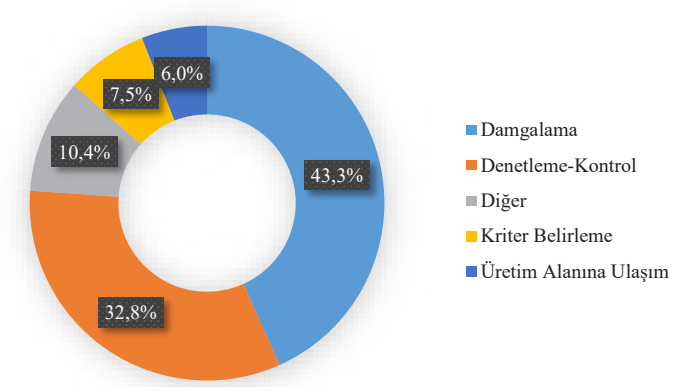

iş kazası frekansları incelenmiş ve geçirilen kaza sayıları esas alınarak kaza geçirme sıklığı gruplandırılmıştır. Buna göre; demografik özelliklerin kaza geçirme sıklığı üzerindeki etkilerini sorgulamak amacıyla son üç yılda kaza geçirdiğini ifade eden çalışanlar esas alınarak 91 gözlem üzerinden analizler gerçekleştirilmiştir (Tablo 2).

Tablo 2. Son üç yılda geçirilen iş kazası sayısı grupları Table 2. Number of occupational accidents in the last three years

\begin{tabular}{ccc}
\hline Kaza Say1s1 Gruplar1 & Frekans & $\%$ \\
\hline 0 & 12 & 11,6 \\
1 & 25 & 24,3 \\
2 & 26 & 25,2 \\
3 & 18 & 17,5 \\
4 ve daha fazla & 22 & 21,4 \\
\hline Toplam & 103 & 100,0 \\
\hline
\end{tabular}

Uygulanan Mann Whitney-U testine ait analiz sonuçlarına göre; "İlköğretim ve altı” öğrenim grubu "Lise ve üstü” öğrenim grubuna göre $\alpha=0,05$ ( $\mathrm{p}=$ 0,022) düzeyinde; "Lise ve altı" öğrenim grubu, "Yükseköğrenim" öğrenim grubuna göre $\alpha=0,01$ $(p=0,0007)$ düzeyinde daha fazla sayıda kaza geçirmektedir (Tablo 3).

Tablo 3. Öğrenim durumuna göre iş kazası geçirme siklı̆̆ 1

Table 3. Frequency of occupational accidents according to education level

\begin{tabular}{clcccc}
\hline & $\begin{array}{l}\text { Öğrenim } \\
\text { Grupları }\end{array}$ & $\mathrm{N}$ & $\begin{array}{c}\text { Sira } \\
\text { Ort. }\end{array}$ & $\mathrm{Z}$ & $\mathrm{p}$ \\
\hline $\begin{array}{c}\text { Kaza } \\
\text { Geçirme }\end{array}$ & $\begin{array}{l}\text { İlköğretim } \\
\text { ve altı }\end{array}$ & 54 & 51,08 & & \\
S1klığ1 & Lise ve üstü & 37 & 38,58 & & \\
& $\begin{array}{l}\text { Lise ve altı } \\
\text { Yükseköğ- } \\
\text { retim }\end{array}$ & 76 & 49,20 & & $0,022^{* *}$ \\
& 15 & 29,80 & $-2,680$ & $0,007 * * *$ \\
& & & \\
\hline
\end{tabular}

**0,05 düzeyinde anlaml1 *** 0,01 düzeyinde anlamlı

Çalışanların yaşının, kaza geçirme sıklığı üzerine etkilerini incelemek için farklı yaş grupları değişkenleri oluşturularak analiz yapılmış; " 25 yaş üstü” ile "25 yaş ve altı" grup arasında kaza geçirme sıklığının $\alpha=0,10 \quad(p=0,083)$ düzeyinde farklı olduğu görülmüştür. Verilerin incelenmesiyle, "25 yaş üstü” olanların daha genç yaş grubuna göre daha az kaza geçirdiği belirlenmiştir (Tablo 4).

Kaza geçirme sıklığının erkekler ve kadınlar arasında farklılık gösterip göstermediği; yine evli ve bekar olmanın farka neden olup olmadığg incelenmiş; ancak istatistiksel olarak anlamlı bir fark görülmemiştir. 
Tablo 4. Yaşa göre iş kazaș geçirme sıklığ Table 4. Frequency of occupational accidents by age

\begin{tabular}{cccccc}
\hline \multirow{2}{*}{$\begin{array}{c}\text { Yaşa } \\
\text { Geçirme }\end{array}$} & Grupları & N & Sira Ort. & Z & p \\
\cline { 2 - 6 } Siklığ1 & $18-25$ yaş & 6 & 63,50 & & \\
& $26-65$ yaş & 85 & 44,76 & $-1,732$ & $0,083^{*}$ \\
\hline
\end{tabular}

*0,10 düzeyinde anlaml 1

\subsubsection{Arazi yapısı ve hava şartlarına göre iş kazaları}

İş kazası anındaki zemin durumu, hava koşulları ve arazi eğimi durumuna göre son üç yılda meydana gelen kaza sayıları ve oranları Tablo 5'te verilmiştir. Buna göre; odun hammaddesi üretiminde tüm çalışanların geçirdikleri kazaların \%32,3'ü "'1slakkaygan”, \%29,2'si “taşlık-kayalık”, \%19,9'u “yoğun diri örtü”, \%16,4'ü "kuru” ve \%2,2'si "karla kaplı" zeminlerde meydana gelmiştir.

Kazalar hava şartlarına göre değerlendirildiğinde \%23,9'u “çok sicak”, \%23,0’ü “yağmurlu”, \%17,3’ü "sisli-puslu”, \%14,2'si "normal”, \%12,4'ü “çok soğuk", \%6,2'si “firtınalı" ve \%3,1'i "karlı" havada gerçekleştiği görülmektedir. Arazi eğimi bakımından ise, \%38,9'u "çok dik", \%34,5'i “dik" ve \%26,5'i “düz” arazilerde kazalar yaşanmıştır (Tablo 5$)$.

Tablo 5. İş kazası anındaki zemin durumu, hava koşulları ve arazi eğimi

Table 5. Ground condition, weather conditions and land slope at the time of occupational accident

\begin{tabular}{|c|c|c|c|c|}
\hline & & Kaza Geçirme & Sayı ${ }^{*}$ & $\%$ \\
\hline \multirow{10}{*}{ Zemin Durumu } & \multirow{2}{*}{ Islak-Kaygan } & Evet & 73 & 32,3 \\
\hline & & Hayır & 153 & 67,7 \\
\hline & \multirow{2}{*}{ Taşlık-Kayalık } & Evet & 66 & 29,2 \\
\hline & & Hayır & 160 & 70,8 \\
\hline & \multirow{2}{*}{ Yoğun Diri Örtü } & Evet & 45 & 19,9 \\
\hline & & Hayır & 181 & 80,1 \\
\hline & \multirow{2}{*}{ Kuru } & Evet & 37 & 16,4 \\
\hline & & Hayır & 189 & 83,6 \\
\hline & \multirow{2}{*}{ Karla Kaplı } & Evet & 5 & 2,2 \\
\hline & & Hayır & 221 & 97,8 \\
\hline \multirow{14}{*}{ Hava Koşulları } & \multirow{2}{*}{ Çok Sicak } & Evet & 54 & 23,9 \\
\hline & & Hayır & 172 & 76,1 \\
\hline & \multirow{2}{*}{ Yağmurlu } & Evet & 52 & 23,0 \\
\hline & & Hayır & 174 & 77,0 \\
\hline & \multirow{2}{*}{ Sisli-Puslu } & Evet & 39 & 17,3 \\
\hline & & Hayır & 187 & 82,7 \\
\hline & \multirow{2}{*}{ Normal } & Evet & 32 & 14,2 \\
\hline & & Hayır & 194 & 85,8 \\
\hline & \multirow{2}{*}{ Çok Soğuk } & Evet & 28 & 12,4 \\
\hline & & Hayır & 198 & 87,6 \\
\hline & \multirow{2}{*}{ Firtınalı } & Evet & 14 & 6,2 \\
\hline & & Hayır & 212 & 93,8 \\
\hline & \multirow{2}{*}{ Karl1 } & Evet & 7 & 3,1 \\
\hline & & Hayır & 219 & 96,9 \\
\hline \multirow{6}{*}{ Arazi Ĕ̆imi } & \multirow{2}{*}{ Çok Dik } & Evet & 88 & 38,9 \\
\hline & & Hayır & 138 & 61,1 \\
\hline & \multirow{2}{*}{ Dik } & Evet & 78 & 34,5 \\
\hline & & Hayır & 148 & 65,5 \\
\hline & \multirow{2}{*}{ Düz } & Evet & 60 & 26,5 \\
\hline & & Hayır & 166 & 73,5 \\
\hline
\end{tabular}

* MOİM'de yapılan anketlere göre son üç yılda toplam 226 kaza meydana gelmiştir. 
Arazi eğiminin kaza geçirme sıklığı üzerindeki etkisini belirlemek amacıyla, düz arazide meydana gelen kaza sayısı ile dik ve çok dik eğime sahip arazilerde meydana gelen kaza sayıları arasında farklılık olup olmadığ 1 Mann Whitney-U testi ile incelenmiştir (Tablo 6). Yüksek eğimli arazide gerçekleşen kaza sayısının, düz arazide gerçekleşen kaza sayısına göre istatistiksel olarak anlamlı düzeyde daha fazla olduğu görülmüştür $(\alpha=0,05)$.

Tablo 6. Arazi eğim durumuna göre iş kazasının meydana gelme siklığ 1

Table 6. Frequency of occupational accidents according to land slope

\begin{tabular}{cccccc}
\hline & $\begin{array}{c}\text { Arazi } \\
\text { Eğim } \\
\text { Durumu }\end{array}$ & N & $\begin{array}{c}\text { Sira } \\
\text { Ort. }\end{array}$ & Z & p \\
\hline $\begin{array}{c}\text { Kaza } \\
\text { Geçirme } \\
\text { Siklı̆ } 1\end{array}$ & Düz & 21 & 36,29 & & \\
\hline
\end{tabular}

**0,05 düzeyinde anlamlı

Son 3 yılda meydana gelen kazalarda, kaza anındaki zeminin durumuna ilişkin veriler esas alınarak kaza geçirme sıklığı ile zeminin sslak-kuru olma, diri örtü yoğunluğu, taşlık-kayalık ve karlı olup olmama özellikleri analiz edilmiştir. Meydana gelen kazaların yoğun diri örtünün bulunduğu zeminde gerçekleşmesinin $\alpha=0,01 \quad(p=0,006)$ düzeyinde, karlı zeminde gerçekleşmesinin $\alpha=0,05$ $(\mathrm{p}=0,043)$ düzeyinde ve taşl1k-kayalık zeminde gerçekleşmesinin $\alpha=0,01 \quad(p=0,00)$ düzeyinde anlamlı bir fark gösterdiği tespit edilmiştir (Tablo 7).

Tablo7. Zemin durumuna göre iş kazasının meydana gelme sıklığ 1

Table 7. Frequency of occupational accidents according to ground condition

\begin{tabular}{lccccc}
\hline \multicolumn{2}{c}{$\begin{array}{c}\text { Zemin } \\
\text { Durumu }\end{array}$} & N & Sira Ort. & Z & p \\
\hline $\begin{array}{l}\text { Yoğun } \\
\text { Diri Örtü }\end{array}$ & Var & 30 & 56,60 & & \\
\hline Yok & 61 & 40,79 & $-2,768$ & $0,006^{* * *}$ \\
Taşl1k- & Var & 43 & 60,51 & & \\
Kayalık & Yok & 48 & 33,00 & $-5,115$ & $0,000^{* * *}$ \\
Kar & Var & 5 & 68,50 & & \\
\hline
\end{tabular}

**0,05 düzeyinde anlamlı *** 0,01 düzeyinde anlamlı

Çalışanların son 3 yılda geçirdiklerini ifade ettikleri kaza sıklığı ile kazaların meydana geldiği andaki hava durumu incelenmiş, meydana gelen kazalarda normal ve yağmurlu havanın istatistiksel açıdan anlamlı fark göstermediği görülmüş; havanın karlı, fırtınalı, çok sıcak ve çok soğuk olmasının ise anlamlı bir fark gösterdiği gözlenmiştir (Tablo 8). Ortalama değerlerin incelenmesiyle, karlı havada $\alpha=0,05(p=0,015)$, firtınalı havada $\alpha=0,01$ $(p=0,001)$, çok sicak havada $\alpha=0,01(p=0,001)$ ve çok soğuk havada $\alpha=0,05 \quad(p=0,017)$ düzeyinde daha fazla kaza meydana geldiği görülmektedir.

Tablo 8. Hava şartlarına göre iş kazasının meydana gelme sıklığ1

Table 8. Frequency of occupational accidents according to weather conditions

\begin{tabular}{lccccc}
\hline Hava şartları & $\mathrm{N}$ & $\begin{array}{c}\text { Sira } \\
\text { Ort. }\end{array}$ & $\mathrm{Z}$ & $\mathrm{p}$ \\
\hline \multirow{2}{*}{ Normal } & Evet & 28 & 46,48 & & \\
& Hayır & 63 & 45,79 & $-0,120$ & 0,905 \\
\multirow{2}{*}{ Yağmurlu } & Evet & 35 & 50,84 & & \\
& Hayır & 56 & 42,97 & $-1,426$ & 0,154 \\
\hline \multirow{2}{*}{ Karlı } & Evet & 6 & 70,50 & & \\
& Hayır & 85 & 44,27 & $-2,424$ & $0,015^{* *}$ \\
\hline \multirow{2}{*}{ Firtınalı } & Evet & 13 & 67,58 & & \\
& Hayır & 78 & 42,40 & $-3,281$ & $0,001^{* * *}$ \\
\hline \multirow{2}{*}{ Çok sıcak } & Evet & 37 & 56,58 & & \\
& Hayır & 54 & 38,75 & $-3,262$ & $0,001^{* * *}$ \\
\hline \multirow{2}{*}{ Çok soğuk } & Evet & 24 & 56,69 & & \\
\cline { 2 - 6 } & Hayır & 67 & 42,17 & $-2,382$ & $0,017^{* *}$ \\
\hline
\end{tabular}

*0,10 düzeyinde anlamlı, **0,05 düzeyinde anlamlı,

*** 0,01 düzeyinde anlamlı

\subsection{Odun hammaddesi üretiminde çalışanların sağlık durumları ve meslek hastalıkları}

Odun hammaddesi üretiminde çalışanların \%70,9'u meslek hayatları süresince tedavi gerektiren bir hastalık tanısı aldığ 1 nı ifade ederken \%29,1'i herhangi bir rahatsızlığının bulunmadığını ifade etmiştir. Üretim işçilerinin \%68,2'sinin rahatsızlığ1 varken, teknik elemanlarda bu oran \%75,7'dir (Tablo 9).

Tablo 1'de görüldüğü üzere 21 y1l ve daha fazla çalışma süresi üretim işçilerinde $\% 34,8$ iken teknik elemanlarda \%56,8'dir. Dolayısıyla teknik elemanlar üretim işçilerine göre daha fazla hizmet süresine sahiptirler ve bu nedenle de daha çok sağlık sorunları yaşayabilmektedirler. 
Tablo 9. Üretim ișinde çalıșanların rahatsızlık durumu Table 9. Health status of production workers

\begin{tabular}{lcccccc}
\hline & \multicolumn{2}{c}{$\begin{array}{c}\text { Üretim } \\
\text { Rahçisi }\end{array}$} & \multicolumn{2}{c}{ Teknik } & \multicolumn{2}{c}{ Toplam } \\
Durumu & Sayı & $\%$ & Say1 & $\%$ & Say1 & $\%$ \\
\cline { 2 - 7 } Yok & 21 & 31,8 & 9 & 24,3 & 30 & 29,1 \\
Var & 45 & 68,2 & 28 & 75,7 & 73 & 70,9 \\
\hline Toplam & 66 & 100,0 & 37 & 100,0 & 103 & 100,0 \\
\hline
\end{tabular}

Üretim işçilerinde görülen sağlık sorunlarının başında \%30,3 ile "bel fitığı" gelmekte olup bunu $\% 24,2$ ile "uykusuzluk", \%22,7 ile "psikolojik" ve \%15,2 ile "ayak-bacak üşümesi” takip etmektedir (Tablo 10).

Teknik elemanların en çok yaşadığı sağlık sorunu \%35,1 ile "uykusuzluk", \% 32,4 ile "tansiyon", \%21,6 ile "psikolojik" ve \% 21,6 ile "bel fitığı" dır (Tablo 10).

Çalışanların mevcut rahatsızlıklarının demografik

Tablo 10. Üretim işinde çalışanların görevlerine göre sağlık sorunlarının durumu Table 10. Status of health problems according to the tasks of production workers

\begin{tabular}{|c|c|c|c|c|c|c|c|}
\hline \multirow{2}{*}{ Sağlık Sorunu } & \multirow{2}{*}{$\begin{array}{l}\text { Mevcut } \\
\text { Durum }\end{array}$} & \multicolumn{2}{|c|}{ Üretim İşçisi } & \multicolumn{2}{|c|}{ Teknik Eleman } & \multicolumn{2}{|c|}{ Toplam } \\
\hline & & Say1 & $(\%)$ & Say1 & $(\%)$ & Say1 & $(\%)$ \\
\hline \multirow{2}{*}{ Uykusuzluk } & Yok & 50 & 75,8 & 24 & 64,9 & 74 & 71,8 \\
\hline & Var & 16 & 24,2 & 13 & 35,1 & 29 & 28,2 \\
\hline \multirow{2}{*}{ Bel Fitığ 1} & Yok & 46 & 69,7 & 29 & 78,4 & 75 & 72,8 \\
\hline & Var & 20 & 30,3 & 8 & 21,6 & 28 & 27,2 \\
\hline \multirow{2}{*}{ Psikolojik } & Yok & 51 & 77,3 & 29 & 78,4 & 80 & 77,7 \\
\hline & Var & 15 & 22,7 & 8 & 21,6 & 23 & 22,3 \\
\hline \multirow{2}{*}{ Tansiyon } & Yok & 59 & 89,4 & 25 & 67,6 & 84 & 81,6 \\
\hline & Var & 7 & 10,6 & 12 & 32,4 & 19 & 18,4 \\
\hline \multirow{2}{*}{ Ayak-Bacak Üşümesi } & Yok & 56 & 84,8 & 32 & 86,5 & 88 & 85,4 \\
\hline & Var & 10 & 15,2 & 5 & 13,5 & 15 & 14,6 \\
\hline \multirow{2}{*}{ Astım } & Yok & 59 & 89,4 & 31 & 83,8 & 90 & 87,4 \\
\hline & Var & 7 & 10,6 & 6 & 16,2 & 13 & 12,6 \\
\hline \multirow{2}{*}{ Cilt Hastalıkları } & Yok & 59 & 89,4 & 33 & 89,2 & 92 & 89,3 \\
\hline & Var & 7 & 10,6 & 4 & 10,8 & 11 & 10,7 \\
\hline \multirow{2}{*}{ Görme Güçlüğü } & Yok & 59 & 89,4 & 34 & 91,9 & 93 & 90,3 \\
\hline & Var & 7 & 10,6 & 3 & 8,1 & 10 & 9,7 \\
\hline \multirow{2}{*}{ Eklem Rahatsızlıkları } & Yok & 63 & 95,5 & 30 & 81,1 & 93 & 90,3 \\
\hline & Var & 3 & 4,5 & 7 & 18,9 & 10 & 9,7 \\
\hline \multirow{2}{*}{ Boyun Fitığ 1} & Yok & 62 & 93,9 & 33 & 89,2 & 95 & 92,2 \\
\hline & Var & 4 & 6,1 & 4 & 10,8 & 8 & 7,8 \\
\hline \multirow{2}{*}{ El-Kol Üşümesi } & Yok & 60 & 90,9 & 35 & 94,6 & 95 & 92,2 \\
\hline & Var & 6 & 9,1 & 2 & 5,4 & 8 & 7,8 \\
\hline \multirow{2}{*}{ Parmaklarda Beyazlık-Uyuşma } & Yok & 61 & 92,4 & 37 & 100,0 & 98 & 95,1 \\
\hline & Var & 5 & 7,6 & 0 & 0,0 & 5 & 4,9 \\
\hline \multirow{2}{*}{ Şeker } & Yok & 64 & 97,0 & 36 & 97,3 & 100 & 97,1 \\
\hline & Var & 2 & 3,0 & 1 & 2,7 & 3 & 2,9 \\
\hline \multirow{2}{*}{ Kalp-Damar } & Yok & 65 & 98,5 & 35 & 94,6 & 100 & 97,1 \\
\hline & Var & 1 & 1,5 & 2 & 5,4 & 3 & 2,9 \\
\hline \multirow{2}{*}{ İşitme Kaybı } & Yok & 66 & 100,0 & 36 & 97,3 & 102 & 99,0 \\
\hline & Var & 0 & 0,0 & 1 & 2,7 & 1 & 1,0 \\
\hline
\end{tabular}

özelliklere göre farklılık gösterip göstermediğini ortaya koymak amaciyla Kruskal Wallis H testi kullanılarak her bir rahatsızlık, demografik özelliklerin farklı aralıkları için oluşturulan değişkenlerle analiz edilmiştir. Çalışanların öğrenim düzeyi ile yapılan analiz sonuçlarının değerlendi- rilmesiyle, uykusuzluğun $\alpha=0,001(p=0,001)$ düzeyinde yükseköğrenim gören çalışanlarda ve görme güçlüğünün ise $\alpha=0,10(p=0,095)$ düzeyinde ilköğretim düzeyinde öğrenime sahip çalışanlarda daha fazla görüldügüü tespit edilmiştir (Tablo 11). 
Tablo 11. Öğrenim düzeyine göre çalışanların rahatsızlık durumu

Table 11. Discomfort status of the employees by level of education

\begin{tabular}{|c|c|c|c|c|}
\hline Rahatsızlık & $\begin{array}{l}\text { Öğrenim } \\
\text { Grupları }\end{array}$ & $\mathrm{N}$ & $\begin{array}{l}\text { Sira } \\
\text { Ort. }\end{array}$ & $\mathrm{p}$ \\
\hline \multirow{3}{*}{ Uykusuzluk } & İlköğretim & 61 & 45,10 & \multirow{3}{*}{$0,001 * * *$} \\
\hline & Lise & 25 & 60,16 & \\
\hline & Yükseköğrenim & 17 & 64,76 & \\
\hline \multirow{3}{*}{$\begin{array}{l}\text { Görme } \\
\text { Güçlüğüü }\end{array}$} & İlköğretim & 61 & 54,60 & \multirow{3}{*}{$0,095^{*}$} \\
\hline & Lise & 25 & 47,00 & \\
\hline & Yükseköğrenim & 17 & 50,03 & \\
\hline
\end{tabular}

*0,10 düzeyinde anlamlı $* * * 0,01$ düzeyinde anlamlı

Çalışanların rahatsızlıklarının, yaşa bağlı olarak farklılık gösterip göstermediği farklı yaş grupları değişkenleri ile analiz edilmiş; uykusuzluk, parmaklarda beyazlık-uyuşma ve astım rahatsızlıklarının 40 yaş sınırına göre farklı olduğu görülmüştür (Tablo 12). Elde edilen sonuçlara göre; "40 yaş altı"ndaki çalışanlar, daha yaşlı olanlara göre $\alpha=0,001 \quad(p=0,001)$ düzeyinde daha fazla uykusuzluk çekmektedir. "40 yaş ve üstü”ndeki üretim işçileri $\alpha=0,1 \quad(p=0,088)$ düzeyinde daha fazla parmaklarda beyazlık-uyuşma rahatsızlığına sahiptir. Yine astım rahatsızlığ " 40 yaş ve üstü”ndeki çalışanlarda istatistiksel olarak anlamlı şekilde $(\alpha=0,05$ düzeyinde) daha fazla görülmektedir $(\mathrm{p}=0,024)$ (Tablo 12).

Tablo 12. Yaş gruplarına göre çalışanların rahatsızlık durumu

Table 12. Discomfort status of the employees by age groups

\begin{tabular}{lccccc}
\hline & Gruplar & $\mathrm{N}$ & $\begin{array}{c}\text { Sira } \\
\text { Ort. }\end{array}$ & $\mathrm{Z}$ & $\mathrm{p}$ \\
\hline Uykusuzluk & $40>$ & 37 & 62,55 & & \\
& $40 \leq$ & 66 & 46,08 & $-3,446$ & $0,001^{* * *}$ \\
\hline $\begin{array}{l}\text { Parmaklarda } \\
\text { Beyazlık }\end{array}$ & $40>$ & 25 & 31,00 & & \\
Uyuşma & $40 \leq$ & 41 & 35,02 & $-1,802$ & $0,071^{*}$ \\
\hline \multirow{2}{*}{ Astım } & $40>$ & 37 & 46,89 & & \\
& $40 \leq$ & 66 & 54,86 & $-2,259$ & $0,024^{* *}$ \\
\hline
\end{tabular}

*0,10 güven düzeyinde anlamlı **0,05 güven düzeyinde anlamlı $* * * 0,01$ güven düzeyinde anlamlı

Rahatsızlık yaşayan çalışanların cinsiyete göre istatistiksel olarak farklı olup olmadıkları Mann Whitney-U testi kullanılarak incelenmiş sonuçları Tablo 13’te verilmiştir. Çalışmanın yapıldı- $\breve{g} 1$ tarihte rahatsızlı̆g 1 bulunan kadınlar erkeklere göre $\alpha=0,05(\mathrm{p}=0,025)$ anlamlılık düzeyinde daha fazladır. Ayak-bacak üşümesi $(\mathrm{p}=0,000)$ ve el-kol üşümesi $\alpha=0,001(\mathrm{p}=0,000)$ anlamlılık düzeyinde, parmaklarda beyazlık-uyuşma $(\mathrm{p}=0,030)$ ve uykusuzluk $\alpha=0,05(\mathrm{p}=0,040)$ anlamlılık düzeyinde, psikolojik rahatsızlık ise $\alpha=0,1(p=0,052)$ anlaml1lık düzeyinde kadınlarda erkeklere göre daha fazla meydana gelmektedir.

Tablo 13. Cinsiyete göre çalışanların rahatsızlık durumu

Table 13. Discomfort status of the employees by gender

\begin{tabular}{|c|c|c|c|c|c|}
\hline Rahatsızlık & Cinsiyet & $\mathrm{N}$ & $\begin{array}{l}\text { Sira } \\
\text { Ort. }\end{array}$ & Z & $\mathrm{p}$ \\
\hline \multirow{2}{*}{$\begin{array}{l}\text { Rahatsızlığ } 1 \\
\text { olma }\end{array}$} & Kadın & 11 & 67,00 & \multirow{2}{*}{$-2,239$} & \multirow{2}{*}{$0,025^{* *}$} \\
\hline & Erkek & 92 & 50,21 & & \\
\hline \multirow{2}{*}{$\begin{array}{l}\text { Parmaklarda } \\
\text { Beyazlık } \\
\text { Uyuşma }\end{array}$} & Kadın & 11 & 58,86 & \multirow[b]{2}{*}{$-2,166$} & \multirow[b]{2}{*}{$0,030^{* *}$} \\
\hline & Erkek & 92 & 51,18 & & \\
\hline \multirow[b]{2}{*}{ Uykusuzluk } & Kadın & 11 & 65,59 & \multirow{2}{*}{$-2,049$} & \multirow[b]{2}{*}{$0,040^{* *}$} \\
\hline & Erkek & 92 & 50,38 & & \\
\hline \multirow[b]{2}{*}{ Psikolojik } & Kadın & 11 & 63,91 & \multirow[b]{2}{*}{$-1,939$} & \multirow[b]{2}{*}{$0,052 *$} \\
\hline & Erkek & 92 & 50,58 & & \\
\hline \multirow{2}{*}{$\begin{array}{l}\text { Ayak-Bacak } \\
\text { Üşümesi }\end{array}$} & Kadın & 11 & 72,59 & \multirow{2}{*}{4557,5} & \multirow{2}{*}{$0,000 * * *$} \\
\hline & Erkek & 92 & 49,54 & & \\
\hline \multirow{2}{*}{$\begin{array}{l}\text { El-Kol } \\
\text { Üşümesi }\end{array}$} & Kadın & 11 & 76,09 & \multirow{2}{*}{$-6,103$} & \multirow{2}{*}{$0,000^{* * *}$} \\
\hline & Erkek & 92 & 49,12 & & \\
\hline
\end{tabular}

*0,10 düzeyinde anlamlı $* * 0,05$ düzeyinde anlamlı $* * * 0,01$ düzeyinde anlamlı

\section{Tartışma ve Sonuç}

Araştırma sonuçlarına göre, odun hammaddesi üretiminde çalışanların ağırlıklı olarak $(\% 89,3)$ erkek olduğu tespit edilmiştir. Erkek egemen sektör olarak nitelendirilen odun hammaddesi üretim faaliyetlerinde, kadınlar gündüz üretim faaliyetlerine yoğun bir şekilde katılmakta, diğer zamanlarda ise yemek, çocuk bakımı, temizlik gibi faaliyetlerle uğraşmaktadırlar. Üretim işlerinde çalışan işçilerin $\% 4,5$ 'i herhangi bir okuldan mezun değildir. \%77,3 gibi büyük bir çoğunluğu ise ilköğretim mezunudur. Y1lın büyük bir bölümünü üretim işlerinde geçiren işçiler ilköğrenimlerini tamamlayıp daha sonraki öğrenimlerine devam etme imkanı bulamamışlar, geçim sıkıntısını aşmak için zorunlu olarak gelir elde etmeye yönelmişlerdir.

Odun hammaddesi üretim işinde çalışanların 
\%88,3'ü son üç yılda en az bir kez iş kazası geçirmiştir. Konu ile ilgili diğer çalışmalarla (Menemencioğlu, 2006; Çolak ve ark., 2011, Özden ve ark., 2011, Gümüş ve Türk, 2012) kıyaslandığında yaşanan iş kazalarının alınan tüm tedbirlere rağmen yüksek oranda olduğu ortaya çıkmıştır. Elde edilen veriler analiz edildiğinde ise öğrenim düzeyi ve yaşın kaza geçirme sıklığını etkilediği belirlenmiştir. Öğrenim düzeyinin, yaşa bağlı olarak farkındalığın ve dikkatin artması, işin inceliklerinin öğrenilmesi ile birlikte kaza geçirme sıklığının azaldığı söylenebilir. Bu alandaki birçok araştırmacı, çalışanların deneyim eksikliği ile kaza oranları arasında anlamlı bir ilişki bulmuştur (Shaffer ve Milburn 1999; Wang ve ark., 2003). Üretim faaliyetleri sirasında aldıkları risklerin daha az farkında olan deneyimsiz işçiler daha çok iş kazaları ile karşı karşıya kalmaktadırlar (Tobisch ve ark., 2005). Bu çalışmada elde edilen "26 yaş ve üstü" çalışanların "18-25 yaş" grubuna göre daha az sayıda kaza geçirdiğine ilişkin bulgu da yukarıdaki ifadeleri destekler niteliktedir.

Odun hammaddesi üretiminde tüm çalışanların son üç yılda geçirdikleri kazaların meydana gelme sıklığının yoğun diri örtünün bulunduğu zeminde, karlı zeminde ve taşlık-kayalık zeminde daha fazla olduğu tespit edilmiştir. Aynı zamanda havanın karlı, firtınalı, çok sıcak ve çok soğuk olması kazaların meydana gelme sıklığını olumsuz etkilemektedir. Eğimli arazide gerçekleşen kaza sayısının, düz arazide gerçekleşen kaza sayısına göre daha fazla olduğu ortaya konulmuştur. Benzer şekilde Enez ve ark. (2014), Trabzon, Gümüşhane ve Rize illerinde gerçekleştirdikleri çalışmalarında iş kazalarının daha çok yağmurlu havalarda $(\% 53,0)$, çok dik eğimli arazilerde $(\% 39,2)$ ve sslak-kaygan zeminlerde $(\% 81,8)$ meydana geldiğini belirtmişlerdir. İş sağlığı ve güvenliği açısından kazaların artmasında etkili olan arazi, zemin ve hava şartlarının durumu göz önünde bulundurularak iş sırasında gereken tedbirler mutlaka alınıp uygulanmalıdır.

Çalışma saatlerinin özellikle işçilerin fiziksel ve zihinsel durumu üzerinde önemli etkisi vardır. Lilley ve ark. (2002), Yeni Zelanda'da yaptıkları çalışmalarında işçilerin günde ortalama 9,4 saat çalıştıklarını, özellikle makine operatörlerinin bakım ve onarımlar nedeni ile bu süreyi daha da aştıklarını belirlemişlerdir. Bu şekilde gerçekleştirilen çalışma süreleri her şeyden önce makine operatörlerinde yorgunluk ve kas ağrısı oluşturarak iş kazalarının oluşmasında büyük bir rol oynamaktadir (Tobish ve ark., 2005). MOİM'de de odun hammaddesi üretim faaliyetlerinde görev alan işçiler günde ortalama 8-10 saat arazide fiilen çalıştıkları$\mathrm{n} ı$ belirtmişlerdir. Özellikle İzmir yöresinde üretim faaliyetlerinin yoğun olduğu dönemde meydana gelen aşırı sıcak hava koşullarının; kesme, sürütme, yükleme, boşatma, istif vb. gibi ağır işlerde hem sağlık için yıpratıcı, hem de üretim verimliliği açısından verimi azaltan önemli etkenlerden olduğu gözlemlenmiştir.

Odun hammaddesi üretiminde çalışanların $\% 70,9$ 'u meslek hayatları süresince tedavi gerektiren bir hastalık tanısı almışlardır. Teknik elemanlar üretim işçilerine göre daha fazla yaş ve hizmet süresine sahip olduklarından daha fazla sağlık sorunları yaşayabilmektedir.

Arazi şartlarının oldukça zorlu ve yapılan işin tehlikeli olması, insan kas gücü kullanımının önemli bir yer tutması, çalışma saatlerinin yoğunluğu ve sosyo-ekonomik sıkıntılar üretim işçilerinin birtakım sağlık sorunlarını yaşamasını beraberinde getirmiştir. Meydana gelen sağlık sorunlarının başında \%30,3 ile "bel fitığı" gelmekte olup bunu \%24,2 ile "uykusuzluk", \%22,7 ile "psikolojik" ve \%15,2 ile "ayak-bacak üşümesi” takip etmektedir. 40 yaş ve üzerindeki üretim işçileri gençlere göre daha fazla "parmaklarda beyazlık-uyuşma" rahatsızlığına sahiptir.

Teknik elemanların en çok yaşadığı sağlık sorunu \%35,1 ile "uykusuzluk", \%32,4 ile "tansiyon", \%21,6 ile "psikolojik" ve \% 21,6 ile "bel fitığ 1 " dir.

Şafak ve Göksu (2016), orman işletme müdürlükleri için potansiyel 2263 adet iş çeşidi saptamış, en fazla iş çeşidinin ise $\% 48,7$ ile işletme ve pazarlama konularında olduğunu belirtmişlerdir.

Aynı zamanda teknik elemanlar iş kazaları ve meslek hastalıklarının oluşmasında rol oynayan en önemli etken olarak aşırı iş yükünü görmektedir. Buna göre, teknik elemanlarda iş yoğunluğuna bağlı olarak uykusuzluk, tansiyon, psikolojik rahatsılıklar görülmekte, açık arazi şartlarında çalışmaktan kaynaklanan bel fitığı ve eklem rahatsızlıklarının da kaçınılmaz bir sonuç olarak ortaya çıktığı anlaşılmaktadır.

Arazi çalışmalarında yapılan gözlem ve analizlere göre; boş zaman kavramı olmayan, hem üretim faaliyetlerinde, hem de ev işlerinde yoğun bir biçimde çalışan kadınların erkeklere göre daha fazla rahatsızlığı bulunmaktadır. Özellikle ayak-bacak üşümesi, el-kol üşümesi, parmaklarda beyazlıkuyuşma, uykusuzluk ve psikolojik rahatsızlıklar kadınlarda erkeklere göre daha fazla meydana gelmektedir. Yine kadınlar erkeklere göre aşırı sıcak ve soğuk havada çalışmaktan sağlık açısından daha olumsuz etkilenmektedirler.

Sağlık sorunlarını mümkün olduğu kadar önlemek 
ve en aza indirgemek için odun üretim işçilerine yapabilecekleri işten fazlası verilmemeli, işe başlamadan önce çalışanlar sağlık kontrolünden geçirilmeli, sağlık açısından uygun olmayan işçi çalıştırılmamalı ve sağlık taramalarının düzenli bir şekilde yapılması gerekmektedir.

Odun hammaddesi üretiminde çalışma koşullarının iyileştirilmesine yönelik düzenlemelerde iş sağlığı ve güvenliğine ilişkin hukuki ve ekonomik yaklaşımlara ek olarak mutlaka üretim faaliyetlerinin insani yönünü de dikkate alacak şekilde uygulamaların gerçekleştirilmesi sağlanmalıdır.

\section{Teşekkür}

Bu makale Orman Genel Müdürlüğü, Ege Ormancılık Araştırma Enstitüsü Müdürlüğü’nce yürütülen 15.5603/2015-2017 numaralı "İş Sağlığ 1 ve Güvenliği Açısından Odun Hammaddesi Üretiminde Risk Değerlendirmesi (Menderes Orman İşletme Müdürlüğü Örneği)" isimli Proje Sonuç Raporunun (Göksu ve ark., 2018) bir bölümünün özetidir. Verdikleri desteklerden dolayı Menderes Orman İşletme Müdürlüğü çalışanlarına çok teşekkür ederiz.

\section{Kaynaklar}

Acar, H., Şentürk, N. 1997. Yusufeli ve İskenderun yöresindeki orman işçilerinde işçi sağlığı üzerine bir araştırma. İstanbul Üniversitesi Orman Fakültesi Dergisi, 47(2), 95-110.

Çolak, N., Tobaş, M., Enez, K., Arıcak, B., Çinar, O., Usta, A., Eren, N., Sevim, A., 2011. Orman Üretim İşçiliğinde İş Kazaları İle Sağlık Sorunlarının Belirlenmesi ve Değerlendirilmesi (Trabzon Orman Bölge Müdürlüğü Örneği) Orman ve Su İşleri Bakanlığı Doğu Karadeniz Ormancılık Araştırma Enstitüsü Müdürlüğü, Teknik Bülten No:27, DKOA Yayın No: 36, ISSN: 1301-800X, Trabzon, 56s.

Enez, K., Topbaş, M., Acar, H., H., 2009. Ormancilıkta üretim işçiliğinde vücut yapıları kaza risk faktörü müdür? 15. Ulusal Ergonomi Kongresi Bildiriler Kitab1, 2224 Ekim 2009, s: 251-258, Konya.

Enez, K., Topbas, M., Acar, H. H., 2014. An evaluation of the occupational accidents among logging workers within the boundaries of Trabzon Forestry Directorate, Turkey. International journal of industrial ergonomics, 44(5), 621-628.

Göksu, E., Başar, H., Elvan, O. D., Erol, M., Şentürk, S., Ceylan, A. R., 2018. İș Sağlığı ve Güvenliği Açısından Odun Hammaddesi Üretiminde Risk Değerlendirmesi
(Menderes Orman İşletme Müdürlüğü Örneği). Ege Ormancılık Araştırma Enstitüsü Müdürlüğü, Proje Sonuç Raporu (yayınlanmamış), Urla-İzmir, 155s.

Gümüş, S., Türk, Y., 2012. Odun hammaddesi üretim işçilerinde bazı sağlık ve güvenlik verilerinin tespitine yönelik bir araştırma. Kastamonu Üniversitesi, Orman Fakültesi Dergisi, 12(1): 20-27.

Lilley, R., Feyer, A. M., Kirk, P., Gander, P., 2002. A survey of forest workers in New Zealand: do hours of work, rest, and recovery play a role in accidents and injury?. Journal of safety research, 33(1), 53-71.

Menemencioğlu, K., 2006. Ormancılıkta üretim işlerinde çalışma koşulları ve iş kazaları üzerine bir araştırma. Türkiye Ormancilık Dergisi, 7(2), 1-12.

Özden, S., Nayır, I., Göl, C., Edıș, S., Yılmaz, H., 2011. Health problems and conditions of the forestry workers in Turkey. African Journal of Agricultural Research, 6(27): 5884-5890. doi: 10.5897/AJAR11.505

SGK (Sosyal Güvenlik Kurumu), 2018. İstatistik Y1llıları. Erişim adresi: http://www.sgk.gov.tr (Ziyaret tarihi:06.09.2019)

Shaffer R., Milburn J., 1999. Injuries on feller-buncher/ grapple skidder logging operations in the South-Eastern United States. Forest Products Journal, 49(7-8), 24-26.

Şafak, İ., Göksu, E., 2016. Türkiye orman işletmelerinde iş çeşitlerinin belirlenmesi: Denizli Orman İşletmesi örneği. Ormancılık Araştırma Dergisi, 1(4A), 114-125.

T.C. Resmi Gazete, 2012. İş Sağlığı ve Güvenliği Kanunu. 28339, 30 Haziran 2012.

T.C. Resmi Gazete, 2017. İş Sağlığı ve Güvenliğine İlişkin İşyeri Tehlike Sınıfları Tebliğinde Değişiklik Yapılmasına Dair Tebliğ. 29992 (Mükerrer), 27 Şubat 2017.

Ünver S., Acar, H. H., Kaya, A., 2013. Odun hammaddesi üretim faaliyetlerinde ergonomik risk değerlendirme yöntemlerine göre incelenmesi. 19. Ulusal Ergonomi Kongresi Bildiriler Kitab1, 27-28-29 Eylül 2013, s:5263., Balıkesir.

Wang, J., Bell, J. L., Grushecky, S. T., 2003. Logging injuries for a 10-year period in Jilin Province of the People's Republic of China. Journal of Safety Research, 34(3), 273-279.

Tobisch R, Walker M, Weise G, 2005.Scientific review of forest machine technical ergonomics. In: Lewark, S., (Editor), Scientific Reviews of Ergonomic Situation In Mechanized Forest Operations. Inst. för skogens produkter och marknader, Sveriges Lantbruksuniversitet. ISSN 1651-114X, pp. 62-86. 